Available online at GSC Online Press Directory

GSC Biological and Pharmaceutical Sciences

e-ISSN: 2581-3250, CODEN (USA): GBPSC2

Journal homepage: https://www.gsconlinepress.com/journals/gscbps

(RESEARCH ARTICLE)

\title{
The efficiency of some plant extracts against Agrotis ipsilon (Lepidoptera: Noctuidae) regarding to their activity on vital biochemical parameters
}

\author{
Ebeid Amany Ramadan * \\ Pests and Plant Protection Department, National Research Centre, Dokki, Cairo, Egypt. \\ Publication history: Received on 20 July 2020; revised on 29 July 2020; accepted on 30 July 2020
}

Article DOI: https://doi.org/10.30574/gscbps.2020.12.1.0229

\begin{abstract}
This study was conducted to evaluate the toxic and harmful effects of Challenger insecticide compared to some plant extracts having insecticidal properties (Conyza aegyptiaca, Melia azedarach, and Vinca rosae) to control Agrotis ipsilon (Hüfn.) (Lepidoptera: Noctuidae). They could be used as alternatives, safer and effective products against many insect pests, also to prevent or minimize the chemical pesticide applications, consequently to keep away the environmental contamination.

The alterations in the nutrient components and digestive enzyme activities in the haemolymph of Agrotis $6^{\text {th }}$ larval instar was determined after feeding the $5^{\text {th }}$ larval instar on castor bean leaves treated with tested plant extracts at $5 \%$ concentration and Challenger insecticide at a concentration of $0.5 \%$. Feeding larvae on these insecticidal materials induced considerable reduction in the total protein, lipids, and carbohydrates, in larval haemolymph. Results recommend that tested insecticidal compounds at such low concentrations can hinder A. ipsilon larval duration, food consumed, and enzymatic possessions. So, the tested insecticidal materials could be applied as a control strategy for this pest.
\end{abstract}

Keywords: Agrotis ipsilon; Challenger insecticide; Plant extracts; Haemolymph composition; Enzymatic activities

\section{Introduction}

The noctuid lepidopteran larvae, Agrotis ipsilon (Hüfn.) (Lepidoptera: Noctuidae), is known as one of the serious insect pest of several important field crops allover the world [1]. Although insecticides are principally applied to control the black cutworm in Egypt [2]. Scintests were still seeking for environment friendly and safe methods to control this insect pest using plant derivatives (secondary plant compounds) as: alkaloids, glycosides, phenolics, uncommon proteins and unusual free amino acids, steroids, essential oils, terpenes, and resins [3], where these compounds have significant insecticidal action. On the other hand, using of these plant derivatives considered a perfect method with no pollution effect on the environment and safe to the natural enemies of the insect pests.

Quite a lot of plant extracts have been applied as Mint, Zygophyllum, Coriander, Arnolosse, Harmel, Neem, Basil, Jasmine, Geranium, etc, as well as their phytochemicals, have been applied by many authors against a large scale of insect pests $[4,5,6]$. Some plant extracts such as Melia azedarach on Spodoptera littoralis (Boisd.) larvae possess antifeedant, growth inhibitory activities, and deterrent effect against larvae of many agriculture pests [7]. On the other hand, some plant extract disrupts nutrient value and activities of some enzymes (amylase, lipase, trehalase, and invertase), which may affect larval growth and development. The activities of amylase, invertase, or protease were stopped in Spodoptera litura (Fabr.) larvae treated with each of neem seed or neem oil emulsified solution [8]. Also, it was found that alkaline protease, amylase, invertase, and alkaline phosphatase activities decreased if Melia azedarach injected into the $6^{\text {th }}$ larval instar of S. litura [9].

\footnotetext{
* Corresponding author: Ebeid Amany Ramadan; email: amanyr2@hotmail.com
} 
The total proteins, lipids, carbohydrate contents are generally the major biochemical components necessary for insect development, growth, synthesize chitin, and perform its vital activities. Feeding of $A$. ipsilon $6^{\text {th }}$ larval instar on petroleum ether extract of (Queen Anne's Lace), Ammi majus L. and Celery (Apium graveolens L.) or acetone and/or ethanol extracts (5\% concentration) of $M$. azedarach and Catharanthus roseus L. reflected a considerable drop in the above mentiond contents of larval haemolymph proportionally to control [10]. Moreover, the alteration in the mid-gut enzymatic activity after Ephestia cautella (Walker) larval treatment with some plant extracts was studied against a variety of insect pests as well [11].

The present work aimed to study the effect of botanical extracts of Melia azedarach \& Vinca rosea, (extracted by petroleum ether), Conyza aegyptiaca (extracted by either alcohol or hexane) and the Challenger $36 \%$ SC insecticide on the $5^{\text {th }}$ larval instar of $A$. ipsilon, also to investigate their effects on the biotic potential. In addition, to evaluate the effects of previous extract on food consumed, weight gained by larvae and determination of total nutrient substances (proteins, carbohydrates, and lipids), as well as some enzymatic activities (amylase, protease, invertase, lipase, trehalase, and trehalose). This may be a tool of using naturally available plant products through Integrated Pest Management programs.

\section{Materials and methods}

\section{$2.1 \quad$ Insect source}

Agrotis ipsilon larvae were obtained from National Research Centre Rearing Laboratory, which maintained for several generations on fresh castor bean, Ricinus communis L. leaves at constant conditions $\left(25 \pm 2{ }^{\circ} \mathrm{C} \& 75 \pm 5 \% \mathrm{RH}\right)$. Newly moulted $5^{\text {th }}$ larval instar were collected from the stock culture and used in bioassay tests.

\section{$2.2 \quad$ Tested materials}

Four Plant extracts were used along with Challenger insecticide as a comparable key with plant extracts used.

\subsubsection{Challenger}

Challenger $36 \%$ SC, a commercial chemical formulation of chlorfenapyr pesticide, manufactured by BASF-The Chemical Company, New Jersey, USA. The recommended concentration (0.5\%) in water with two drops of Tween-80, as emulsifier was used [12].

\subsubsection{Plant extracts}

Petroleum ether extracts of M. azedarach and V. rosea

Samples of two local plant species belonging to different families were used. Aerial part (leaves) from the periwinkle, $V$. rosea (Apocynaceae), and Chinaberry, M. azedarach (Meliaceae) used for extraction processes according to Abou ElGhar et al. [10].

Ethanolic and hexane extracts of Egyptian Conyza, Conyza aegyptiaca (L.) (Order: Asterales- Family: Asteraceae):

Egyptian Conyza was collected from Sinai, Egypt. The whole plant was dried in shad, finely powdered, and successively extracted with two solvents (hexane and ethanol separately) until exhaustion. Solvents were evaporated under reduced pressure at $40^{\circ} \mathrm{C}$ until dryness then the residues were weighted. The concentration of $5 \%$ for all extracts was prepared by mixing $5 \mathrm{ml}$ of the extract with $100 \mathrm{ml}$ water then adding three drops of the emulsifier (Triton X-100) [12].

\subsection{Bioassay tests}

According to Ebeid et al. [12], the newly moulted $5^{\text {th }}$ instar larvae of $A$. ipsilon in each treatment were weighed before and after the experiment to evaluate the weight gained (subtracting weight at the end from the weight at the beginning of the experiment). Then each larva reared individually in plastic cups ( $4 \mathrm{~cm}$ diameter $\mathrm{x} 5 \mathrm{~cm}$ depth) and provided daily with a fixed weight of fresh castor leaves, that treated with either plant extracts (5\% emulsion) or insecticide (Challenger at $0.5 \%$ concentration) and covered with muslin. The remaining leaves reweighed at the end of the experiment to evaluate the weight of consumed food (initial fixed weight of leaves - remaining leaves). The Leaves treated with only water with two drops of tween-80 (as an emulsifier) served as control (check). The remaining survived larvae which reached to the $6^{\text {th }}$ larval instar in each treatment were collected after another $72 \mathrm{~h}$ of feeding fresh untreated leaves then starved for $12 \mathrm{~h}$ before carrying out the biochemical assays. Each treatment comprised 30 larvae; the whole experiment was replicated three times. 


\subsection{Biochemical determinations}

\subsubsection{Haemolymph samples}

Haemolymph for chemical analysis was drawn from one or two of the thoracic legs of survived larvae in each treatment to be used for bioassays according to Knight et al. [13].

\subsubsection{Determinations of total proteins, lipids, and carbohydrates}

The content of total proteins in haemolymph was determined with the method described by Henry [14] which based on the principle of Biuret reaction. Haemolymph lipids were determined by the sulphophosphovanillin method [13]. Total haemolymph carbohydrates were determined with the method described by Singh and Sinha [15].

\subsubsection{Determinations the activity of some enzymes (amylase, invertase, and trehalase activities)}

Haemolymph invertase and amylase activities were assayed colorimetrically according to the methods describing by Ishaaya and Casida [16]. Trehalase, protease, and lipase activities were assayed according to Ishaaya and Swirski [17].

\subsection{Statistical analysis}

All data obtained for biological and biochemical studies were statistically analyzed using ANOVA through the SPSS computer program. Mean differences were calculated according to the Duncan Multiple Range Test [18] at a $5 \%$ level of probability.

\section{Results}

\subsection{Growth disruptive effects}

Feeding of $A$. ipsilon larvae with castor plant leaves treated with Challenger insecticide, Conyza-hexane, $V$. rosea, $M$. azedarach, and Conyza-alcohol extracts significantly exhibited decrease the amount of food consumed after 24 hours of feeding. Such reduction in larval feeding caused by the above-tested insecticides induced a significant decrease in larval weight (Table 1). Results indicated that Challenger insecticide, Conyza-hexane, and V. rosea extracts were more effective in retarding larval growth than that treated with either M. azedarach or Conyza-alcohol extract (Table 1).

\subsection{Larval haemolymph composition}

\subsubsection{Proteins}

The results summarized in table (1) show that feeding of A. ipsilon larvae on castor plant leaves treated with $5 \%$ concentration of both $M$. azedarach \& $V$. rosea extracts and Challenger insecticide $(0.5 \%)$, resulted in a reduction of total content of haemolymph proteins reached to $2.14,2.90$ and $1.70 \mathrm{mg} / \mathrm{ml}$ (equal 1.86, 1.38 and 2.35 folds), respectively less than the check $(3.99 \mathrm{mg} / \mathrm{ml})$; all tested insecticidal agents being significantly different with control except Conyzahexane extract $\left(\mathrm{F}_{5,24}=63.352^{* *}, P=0.000\right)$, i.e., this reduction could be resembled by $(-46.37,-27.32$ and $-57.39 \%)$ relative to the check (Table 1$)$.

\subsubsection{Lipids}

The same trend was observed, where feeding larvae on castor leaves treated with M. azedarach, V. rosea extracts and Conyza-alcohol extract greatly reduced haemolymph lipids to reach $47.3,34.0$ and $53.7 \mathrm{mg} / \mathrm{ml}$, being significantly different with the check $(109.01 \mathrm{mg} / \mathrm{ml})\left(\mathrm{F}_{5,24}=887.831^{* *}, P=0.000\right)$; achieving the most reduction percentage equal to $(-56.61 \%),(-68.81 \%)$ and $(-50.34 \%)$, relatively to that of the control (Table 1). Likewise, both Challenger insecticide and Conyza-alcohol extract, significantly lower the haemolymph lipids too with less reduction percentages reached to $(-8.27 \%)$, and $(-28.63 \%)$, respectively with respect to the control.

\subsubsection{Carbohydrates}

Results indicated that feeding larvae on the treated leaves with $V$. rosea extract and Challenger insecticide greatly reduced total haemolymph carbohydrates to reach 1.99 and $2.70 \mathrm{mg} / \mathrm{ml}$; being significantly different with the check $(4.99 \mathrm{mg} / \mathrm{ml})\left(\mathrm{F}_{5,24}=26.496^{* *}, P=0.000\right)$ i.e., it resembled with $(-60.12 \&-45.89 \%$ reduction) relatively to the control (Table 1). Furthermore, both Conyza-alcohol and hexane extract lowering the haemolymph carbohydrates to reach 3.10 and $3.07 \mathrm{mg} / \mathrm{ml}$, respectively, being significantly different too with the check $(4.99 \mathrm{mg} / \mathrm{ml})$, but insignificantly with each other, this reduction bears a resemblance to $(-37.88 \&-38.48 \%)$ relative to the control (Table 1$)$. 
Table 1 Effect of feeding Agrotis ipsilon $5^{\text {th }}$ larval instar on castor bean leaves treated with several plant extracts (at $5 \%$ conc.) and Challenger (at $0.5 \%$ conc.) on food consumption, larval weight and total haemolymph contents (proteins, lipids and carbohydrates)

\begin{tabular}{|c|c|c|c|c|c|}
\hline \multirow[t]{2}{*}{ Treatments } & $\begin{array}{l}\text { Weight of food consumed } \\
\text { (mg/larvae }\end{array}$ & $\begin{array}{l}\text { Larval weight gain } \\
\text { (mg/larvae) }\end{array}$ & $\begin{array}{l}\text { Protein } \\
\text { (mg/ml) }\end{array}$ & $\begin{array}{l}\text { Lipid } \\
\text { (mg/ml) }\end{array}$ & $\begin{array}{l}\text { Carbohydrate } \\
(\mathrm{mg} / \mathrm{ml})\end{array}$ \\
\hline & \multicolumn{5}{|l|}{ Means \pm SE } \\
\hline Melia azedarach & $\begin{array}{l}106.20 \pm 1.79 c \\
(-68.15 \%)\end{array}$ & $\begin{array}{l}66.90 \pm 1.10 b \\
(-60.41) \%\end{array}$ & $\begin{array}{l}2.14 \pm 0.23 \mathrm{~d} \\
(-46.37 \%)\end{array}$ & $\begin{array}{l}47.30 \pm 0.36 \text { e } \\
(-56.61 \%)\end{array}$ & $\begin{array}{l}2.90 \pm 0.33 \mathrm{~b} \\
(-41.88 \%)\end{array}$ \\
\hline Vinca rosea & $\begin{array}{l}99.01 \pm 2.53 \mathrm{~d} \\
(-70.30 \%)\end{array}$ & $\begin{array}{l}55.00 \pm 1.47 c \\
(-67.75 \%)\end{array}$ & $\begin{array}{l}2.90 \pm 0.14 \mathrm{c} \\
(-27.32 \%)\end{array}$ & $\begin{array}{l}34.00 \pm 1.79 f \\
(-68.81 \%)\end{array}$ & $\begin{array}{l}1.99 \pm 0.16 c \\
(-60.12 \%)\end{array}$ \\
\hline Conyza-alcohol & $\begin{array}{l}242.04 \pm 3.55 b \\
(-27.40 \%)\end{array}$ & $\begin{array}{l}54.50 \pm 1.04 \mathrm{c} \\
(-67.46 \%)\end{array}$ & $\begin{array}{l}3.60 \pm 0.10 \mathrm{~b} \\
(-9.77 \%)\end{array}$ & $\begin{array}{l}53.70 \pm 1.16 \mathrm{~d} \\
(-50.74 \%)\end{array}$ & $\begin{array}{l}3.10 \pm 0.17 b \\
(-37.88 \%)\end{array}$ \\
\hline Conyza-hexane & $\begin{array}{l}73.40 \pm 1.11 \mathrm{e} \\
(-77.98 \%)\end{array}$ & $\begin{array}{l}24.00 \pm 1.38 d \\
(-85.80 \%)\end{array}$ & $\begin{array}{l}3.90 \pm 0.10 \mathrm{ab} \\
(-2.26 \%)\end{array}$ & $\begin{array}{l}77.80 \pm 0.70 \mathrm{c} \\
(-28.63 \%)\end{array}$ & $\begin{array}{l}3.07 \pm 0.05 b \\
(-38.48 \%)\end{array}$ \\
\hline Challenger 36\% SC & $\begin{array}{l}50.88 \pm 1.69 f \\
(-84.74 \%)\end{array}$ & $\begin{array}{l}12.67 \pm 0.79 \mathrm{e} \\
(-92.50 \%)\end{array}$ & $\begin{array}{l}1.70 \pm 0.18 \text { e } \\
(-57.39 \%)\end{array}$ & $\begin{array}{l}100.00 \pm 0.55 b \\
(-8.27 \%)\end{array}$ & $\begin{array}{l}2.70 \pm 0.24 b \\
(-45.89 \%)\end{array}$ \\
\hline Control & $333.40 \pm 1.46 \mathrm{a}$ & $169.00 \pm 1.58 \mathrm{a}$ & $3.99 \pm 0.11 \mathrm{a}$ & $109.01 \pm 0.83 \mathrm{a}$ & $4.99 \pm 0.09 \mathrm{a}$ \\
\hline$F_{5,24}$ & $2624.407^{* *}$ & $1953.056^{* *}$ & $63.352^{* *}$ & $887.831^{* *}$ & $26.496^{* *}$ \\
\hline$P$-value & 0.000 & 0.000 & 0.000 & 0.000 & 0.000 \\
\hline
\end{tabular}

Values between bracts = Enzyme activities percentage with respect to the control.

Means followed with the same letter(s) in a single column are insignificantly differ $(P=5 \%)$ 


\subsection{Enzyme activities}

Table (2) the activity of haemolymph contents of A. ipsilon $5^{\text {th }}$ instar larvae that feed on leaves treated with $5 \%$ emulsion of tested plant extracts or $0.5 \%$ insecticide concentration and reached $6^{\text {th }}$ larval instar were assayed after $72 \mathrm{~h}$ feeding.

\subsubsection{Amylase}

The Challenger insecticide, $V$. rosea extract, and Conyza-alcoholic extract significantly affected amylase enzyme activity to achieve the percentage of reduction reached to [-57.20, -54.66 and $-51.26 \%$, respectively], with respect to the control. The same tendency, larvae fed on leaves treated with $M$. azedarach and Conyza-hexane extracts showed a lower significant reduction for amylase activity with percentage reached about $(-39.59 \&-12.54 \%)$ decreased respectively; being significantly different between each other and all other treatments. On the other side, Amylase activity, in all treatments, achieved a highly significant difference when compared with the check $\left(\mathrm{F}_{5,24}=201.537^{* *}, P=0.000\right)(\mathrm{Table}$ 2).

\subsubsection{Protease}

The corresponding figure for protease activity, M. azedarach extract and Challenger insecticide induced a significant decline in enzyme activity reached 17.22 and $10.65 \mathrm{mg} / \mathrm{ml}$, being significantly different from the check $(25.44 \mathrm{mg} / \mathrm{ml})$, where the reduction percentage resembled $(-32.31 \&-58.14 \%$, respectively) as for the control treatment. On the other hand, larval feeding on ethanol extract from $V$. rosea and Conyza-alcoholic extracts showed a lower significant reduction for amylase activity to reach $20.59(-19.06 \%)$ and $19.46(-23.51 \%)$, respectively, than that in control treatments. All treatments statistically induced highly significant differences compared to the check $\left(\mathrm{F}_{5,24}=191.671^{* *}, P=0.000\right)(\mathrm{Table}$ 2).

\subsubsection{Invertase}

Results presented in Table (2) show also that feeding larvae leave treated with Melia and Vinca extracts, slightly reduced haemolymph-invertase activity, while in the case of Challenger and Conyza-hexane extract treatments realize significant highest reductions in the enzyme activity. Almost all treatments induced high significant differences than the control $\left(\mathrm{F}_{5,24}=80.879^{* *}, P=0.000\right)$ (Table 2).

\subsubsection{Lipase}

Feeding larvae on tested plant extracts or insecticide resulted in a significant disturbance in haemolymph lipase activity. For example, leaves treated with $M$. azedarach and $V$. rosea extracts resulted in a high increase in lipase activity percentages of the larval stage reached to 4.17 and $3.92 \mathrm{mg} / \mathrm{ml}$ compared to the control (3.55 $\mathrm{mg} / \mathrm{ml}) ; \mathrm{being}$ insignificantly different between each other but the former was significantly differ $\left(\mathrm{F}_{5,24}=19.873^{* *}, P=0.000\right)$ equal to about 1.17 and 1.10 fold, respectively, more than in control treatment (Table 2). On the other hand, Conyza-alcohol extract, Conyza-hexane extract and Challenger induced a reduction effect ranged between -34.93 to $-5.92 \%$, compared with that of control (Table 2).

\subsubsection{Trehalase}

Data in the table (2) also demonstrated either an increase or decrease in haemolymph trehalase activity when larvae feeding on treated leaves. For example, feeding larvae on leaves treated with $V$. rosea extract and Challenger insecticide resulted in a high increase in trehalase activity by about 1.32 and 1.29 fold, respectively, more than that in the control treatment. Where all other treatments induced a different percentage of decrease than that for control. Statistically, all treatments induced significant differences between each other as well as the control treatment $\left(\mathrm{F}_{5,24}=41.655^{* *}\right.$, $P=0.000$ ) (Table 2).

\subsubsection{Trehalose}

All tested insecticidal agents that applied on A. ipsilon 5th instar larval feeding, negatively affect the activity of the trehalose enzyme significantly $\left(F_{5,24}=174.824^{* *}, P=0.000\right)$ due to the severe reduction content with respect to the control (Table2). 
Table 2 Determination of the changes in haemolymph enzymes activities in Agrotis ipsilon 6th larval instar post feeding on castor bean leaves treated with plant extracts (at $5 \%$ conc.) and Challenger insecticide (at $0.5 \%$ conc.) for 72 hour

\begin{tabular}{|c|c|c|c|c|c|c|}
\hline \multirow[t]{2}{*}{ Plant extract } & \multicolumn{6}{|c|}{$\begin{array}{l}\text { Enzymes determination } 3 \text {-days post treatment } \\
\text { Means } \pm \text { SE }\end{array}$} \\
\hline & Amylase & Protease & Invertase & Lipase & Trehalase & Trehalose \\
\hline Melia azedarach & $\begin{array}{l}21.34 \pm 0.19 \mathrm{c} \\
(-39.59 \%)\end{array}$ & $\begin{array}{l}17.22 \pm 0.27 \mathrm{~d} \\
(-32.31 \%)\end{array}$ & $\begin{array}{l}102.70 \pm 0.78 \mathrm{a} \\
(-2.28 \%)\end{array}$ & $\begin{array}{l}4.17 \pm 0.55 \mathrm{a} \\
(+\mathbf{1 7 . 4 6 \% )}\end{array}$ & $\begin{array}{l}29.11 \pm 0.79 \mathrm{~b} \\
(-4.37 \%)\end{array}$ & $\begin{array}{l}0.12 \pm 0.01 c \\
(-63.64 \%)\end{array}$ \\
\hline Vinca rosea & $\begin{array}{l}16.02 \pm 0.43 \text { de } \\
(-54.66 \%)\end{array}$ & $\begin{array}{l}20.59 \pm 0.20 b \\
(-19.06 \%)\end{array}$ & $\begin{array}{l}97.22 \pm 0.53 b \\
(-7.49 \%)\end{array}$ & $\begin{array}{l}3.92 \pm 0.13 \mathrm{ab} \\
\mathbf{( + 1 0 . 4 2 \% )}\end{array}$ & $\begin{array}{l}40.20 \pm 0.65 a \\
(+32.06 \%)\end{array}$ & $\begin{array}{l}0.22 \pm 0.01 b \\
(-33.33 \%)\end{array}$ \\
\hline Conyza-alcohol & $\begin{array}{l}17.22 \pm 0.32 \mathrm{~d} \\
(-51.26 \%)\end{array}$ & $\begin{array}{l}19.46 \pm 0.61 c \\
(-23.51 \%)\end{array}$ & $\begin{array}{l}90.3 \pm 1.62 \text { c } \\
(-14.08 \%)\end{array}$ & $\begin{array}{l}2.31 \pm 0.10 \text { e } \\
(-34.93 \%)\end{array}$ & $\begin{array}{l}29.10 \pm 1.72 b \\
(-4.40 \%)\end{array}$ & $\begin{array}{l}0.07 \pm 0.01 \mathrm{e} \\
(-78.79 \%)\end{array}$ \\
\hline Conyza-hexane & $\begin{array}{l}30.9 \pm 0.99 b \\
(-12.54 \%)\end{array}$ & $\begin{array}{l}17.44 \pm 0.74 \mathrm{~d} \\
(-31.45 \%)\end{array}$ & $\begin{array}{l}86.22 \pm 0.88 d \\
(-17.96 \%)\end{array}$ & $\begin{array}{l}2.99 \pm 0.18 d \\
(-15.77 \%)\end{array}$ & $\begin{array}{l}22.97 \pm 0.42 \mathrm{c} \\
(-24.54 \%)\end{array}$ & $\begin{array}{l}0.11 \pm 0.01 \mathrm{~cd} \\
(-66.67 \%)\end{array}$ \\
\hline Challenger 36\% SC & $\begin{array}{l}15.12 \pm 0.59 \text { e } \\
(-57.20 \%)\end{array}$ & $\begin{array}{l}10.65 \pm 0.66 \mathrm{e} \\
(-58.14 \%)\end{array}$ & $\begin{array}{l}77.20 \pm 0.92 \mathrm{e} \\
(-26.55 \%)\end{array}$ & $\begin{array}{l}3.34 \pm 0.08 \mathrm{~cd} \\
(-5.92 \%)\end{array}$ & $\begin{array}{l}39.33 \pm 1.24 \mathrm{a} \\
(+29.20 \%)\end{array}$ & $\begin{array}{l}0.09 \pm 0.01 \mathrm{de} \\
(-72.73 \%)\end{array}$ \\
\hline Control & $35.33 \pm 0.71 \mathrm{a}$ & $25.44 \pm 0.51 \mathrm{a}$ & $105.10 \pm 1.78 \mathrm{a}$ & $3.55 \pm 0.08 \mathrm{bc}$ & $30.44 \pm 0.81 \mathrm{~b}$ & $0.33 \pm 0.01 \mathrm{a}$ \\
\hline$F_{5,24}$ & $201.537^{* *}$ & $191.671^{* *}$ & $80.879 * *$ & $19.873^{* *}$ & $41.655^{* *}$ & $174.824^{* *}$ \\
\hline$P$-value & 0.000 & 0.000 & 0.000 & 0.000 & 0.000 & 0.000 \\
\hline
\end{tabular}




\section{Discussion}

The results from these experiments showed adverse effects of consumed treated leaves on larval growth, haemolymph supplement content, and the activities of some digestive enzymes. The main factor affecting larval growth and development is disrupting feeding; where the larvae stop feeding, their body weight rapidly influenced negatively, mainly due to disturbance in metabolites, secretion and the action of digestive enzymes or due to dehydration of larval tissues during their development [19].

Haemolymph nutrient (carbohydrate, protein, and lipids) are important elements for insect growth, development, the energy required for vital biological functions and take part in the occurrence of the anabolic and catabolic processes [20]. In this study, Challenger insecticide followed by M. azedarach concentrations (at $0.5 \%$ and $5 \%$, respectively), induced the most significantly decrease in protein content, which disturbs all metabolic processes by the conversion of proteins into amino acids to compensate this decline into energy due to the stress effect of pesticide [20]. Present results were mismatched with those reported by He et al. [21] who mentioned that such enzymes maintain the treated insects alive, and its action may result in an augmentation in total protein after insecticidal application.

The carbohydrate constituent was clearly diminished when either $V$. rosea extract or Challenger insecticide was applied to A. ipsilon larvae that might be because of dropping in food consumption. A similar pattern was seen in case of amylase activity after getting in touch with the aforementioned insecticides, which resulted in a shortage of the conversion process of glycogen to glucose and hydrolysis of starch to maltose as recorded results [22].

Additionally, V. rosea and M. azedarach significantly disturbed the lipid content metabolism and lipase secretion which may be due to the treatment with these insecticidal agents, these results matched with Zibaee \& Bandani [23]. Furthermore, various investigations have focused on the adverse effect of chemical insecticide on lipid content and lipase action $[22,24]$.

Our study showed that insect carbohydrate reserves are present as trehalose that decreased sharply in larvae fed on all tested insecticidal agents, which can be readily converted to glucose for chitin synthesis this result matched with Mohamed [25]. Some studies showed that the trehalose content helps insects to select their food, affect feeding behaviour for them and prevent protein denaturation due to the effect of adverse conditions; therefore, it normalizes growth and maturity of insect pests $[25,26]$.

Trehalase is generally present in large amounts in the haemolymph of most insects that have the important function of flight and during moulting cycles. The activity of haemolymph trehalase in this experiment seemed to be much more than that in the control treatment. This behaviour may produce glucose, which was used to build chitin for the cuticle formation process [27].

Protease action decreased significantly once exposure to each one of the tested insecticidal materials. This result was in conversely with Rasha et al. [1] on A. ipsilon; and reliable with other findings, which pointed out that benzothiazole or Chlorfenapyr insecticides hold down protease achievement in Bradysia odoriphaga [20, 22]. Several insecticides have been successfully used for controlling $A$. ipsilon for many years, and many growers used to rely solely on these insecticides one season after another [24]. One of these insecticides, Challenger $36 \%$ SC which is a pro-insecticide, i.e. its biological activity depends on its conversion to other toxic compounds [12].

Conyza aegyptiacae either alcohol and/or hexane extracts were considered to be proper to continue in vivo assays because of their effects on the survival of larvae. Decreasing survival in the case of Conyza-alcoholic extract and Challenger insecticide was due to their toxicity, similar observations have been reported by Oigiangbe et al. [28].

\section{Conclusion}

Great effects were found in the development and survival of the larvae treated with the plant extracts. According to the obtained results, the little values of the larval weight gained, the few numbers of larvae that remained alive were rudiment or small size with sluggish and moribund symptoms, while the control untreated larvae complete their larval stage. The obtained results suggested an interesting opportunity to develop bio-insecticides based on plant extracts to control this serious lepidopteran pest and other pests. From this point of view, it could be recommended the usage of the previously mentioned plant extracts that decrease insect resistance build-up as biological agents, and safe alternatives methods through the IPM program. 


\section{Compliance with ethical standards}

\section{Acknowledgments}

The authors are very grateful to all colleges, Pests and Plant Protection Department, National Research Centre, for their valuable advice and help.

\section{Disclosure of conflict of interest}

The authors declare that they have no competing interests.

\section{References}

[1] El-Hosary RA, Yacoub SHS and EL-Hefny AS. (2013). Effect of some plant extracts on black cutworm Agrotis ipsilon (Hüfn.) under laboratory conditions. Agricultural Research, 91(2), 495.

[2] Ebeid AR, Gesraha MA and Abdou WL. (2017). Effects of Cyfluthrin Insecticide on Agrotis ipsilon Immature Stages Development with Respect to Different Temperatures. Annual Research \& Review in Biology, 15(6), 1-9.

[3] Kingsbury JM. (1983). The evolutionary and ecological significance of plant toxins. p. 675-706. In: R.F. Keeler and A.T. Tu (eds.) Handbook of Natural Toxins, Marcel Dekker, Inc., N.Y.

[4] Shapiro M, Robertsojn L and Webb RE. (1994). Effect of neem seed extract upon the gypsy moth (Lepidoptera: Lymantriidae) and its nuclear polyhedrosis virus. Journal of Economic Entomology, 87, 356-360.

[5] Sharaby A and Fallatah SAB. (2019). Protection of stored potatoes from infestation with the potato tuber moth, Phthorimaea operculella (Zeller) (Lepidoptera: Gelechiidae) using plant powders. Bulletin of the National Research Centre (Egypt), 43, 79-85.

[6] Sharaby A, Gesraha MA and Fallatah SAB. (2019). Integration of some Biopesticides against potato tuber moth, Phthorimaea operculella (Zell.) during storage with reference to histopathlogical changes detected by transmission electron microscope in endocrine system. Bulletin of the National Research Centre (Egypt), 43, 122137.

[7] Khadr GA, EL-Monem EMA and Taha MA. (1986). Effect of Melia azedarach extract on Spodoptera littoralis (Boised) larvae in the labortatory. Bulletin of the Entomological Society of Egypt, Economic Series, 15, 235-243.

[8] Rajendran R and Abdul Kareem A. (1978). Studies on the effects of plant products and organotin compounds as antifeedants on the activity of amylase and protease in larvae of Spodoptera litura F. (Lepidoptera) on sweetpotato (Ipomoea batatas Lamb). South Indian Horticulture, 26(1), 14-17.

[9] Ayyanga SG and Rao PJ. (1990). Azadirachtin effects on consumption and utilization of food and mid-gut enzymes of Spodoptera litura (Fabr.). Indian Journal of Entomology, 51, 373-376.

[10] Abou El-Ghar GES, Khalil ME and Eid TM. (1996). Some biochemical effects of plant extracts in the black cutworm, Agrotis ipsilon (Hüfn.) (Lep., Noctuidae). Journal of Applied Entomology, 120(8), 482-477.

[11] Boshra SA. (2007). Effect of gamma irradiation on food consumption, assimilation and digestive enzymes in Ephestia cautella (Walker) larvae. Journal of Stored Product Research, 43(1), 49-52.

[12] Ebeid AR, Sammour EA and Zohdy NZ. (2014). Role of Challenger pesticide and plant extracts on some physiological parameters of the cotton leafworm, Spodoptera littoralis (Boisd.). Archives of Phytopathology and Plant Protection, 48(5), 385-392.

[13] Knight JA, Anderson S and Rawle JM. (1972). Chemical basis of the sulpho-phospho-vanillin reaction for estimating total lipids. Clinical Chemistry, 18(3), 199-202.

[14] Henry RJ. (1964). Determination of serum proteins by means of the biuret reaction. Clinical Chemistry, Harper and Row publishers New York, 181.

[15] Singh NB and Sinha RN. (1977). Carbohydrates, lipids and protein in the developmental stages of Sitophilus oryzea and Sitophilus grannarius. Annals of the Entomological Society of America, 107-111.

[16] Ishaaya I and Casidaj E. (1975). Phenyltin compounds inhibit digestive enzymes of Triboliuni confirsum larvae. Pesticide Biochemistry and Physiology, 5, 350-358. 
[17] Ishaaya I and Swirski E. (1976). Trehalase, invertase and amylase activities in the black scale Saissetia oleae, and their relation to host adaptability. Journal of Insect Physiology, 22, 1025-1029.

[18] Duncan DB. (1955). Multiple ranges and multiple F-test. Biometrics, 11, 1-42.

[19] Sehnal F, Janda V and jr., Sasnikova O. (1966). Über den Einfluß des Juvenil hormons auf den Glycogen-Fett- und Stickstoff-metabolismus der Larven von Galleria mellonella. Zool Jb, Abt allgem Zool Physiol, 72, 327-337.

[20] Zhao Y, Wang Q, Ding J, Wang Y, Zhang Z, Liu F and Mu W. (2018). Sublethal effects of chlorfenapyr on the life table parameters, nutritional physiology and enzymatic properties of Bradysia odoriphaga (Diptera: Sciaridae). Pesticide Biochemistry and Physiology, 148, 93-102.

[21] He F, Sun S, Tan H, Sun X, Qin C, Ji S, Li X, Zhang J and Jiang X. (2019). Chlorantraniliprole against the black cutworm Agrotis ipsilon (Lepidoptera: Noctuidae): From biochemical/physiological to demographic responses. Scientific Reports, 1-7.

[22] Zhao Y, Xu C, Wang Q, Wei Y, Liu F, Xu S, Zhang Z and Mu W. (2016). Effects of the microbial secondary metabolite benzothiazole on the nutritional physiology and enzyme activities of Bradysia odoriphaga (Diptera: Sciaridae). Pesticide Biochemistry and Physiology, 129, 49-55.

[23] Zibaee A and Bandani AR. (2010). Effects of Artemisia annua L. (Asteracea) on the digestive enzymatic profiles and the cellular immune reactions of the Sunn pest, Eurygaster integriceps (Heteroptera: Scutellaridae) against Beauvaria bassiana. Bulletin of Entomological Research, 100, 185-196.

[24] Xu C, Ding J, Zhao Y, Luo J, Mu W and Zhang Z. (2017). Cyantraniliprole at sublethal dosages negatively affects the development, reproduction, and nutrient utilization of Ostrinia furnacalis (Lepidoptera: Crambidae). Journal of Economic Entomology, 110, 230-238.

[25] Mohamed TRS. (1998). Biochemical and physiological studies of some insect growth regulators on the cotton leafworm, Spodoptera littoralis (Boisd.). Ph.D. Thesis, Faculty of Science, Cairo University.

[26] Yazdani E, Sendi JJ, Aliakbar A and Nathan-Nathan SS (2013). Effect of Lavandula angustifolia essential oil against lesser mulberry pyralid Glyphodes pyloalis Walker (Lep: Pyralidae) and identification of its major derivatives. Pesticide Biochemistry and Physiology, 107, 250-257.

[27] Candy DJ and Kliby BA. (1962). Studies of chitin synthesis in the desert locust. Journal of Experimental Biology, $39,129-140$.

[28] Oigiangbe ON, Igbinosa IB and Tamo M. (2007). Insecticidal activity of the medicinal plant, Alstonia boonei De Wild, against Sesamia calamistis Hampson. Journal of Zhejiang University, Science, B, 8, 752-755.

\section{How to cite this article}

Ebeid AR. (2020). The efficiency of some plant extracts against Agrotis ipsilon (Lepidoptera: Noctuidae) regarding to their activity on vital biochemical parameters. GSC Biological and Pharmaceutical Sciences, 12(1), 240-248. 